\author{
Maria Szajny \\ Uniwersytet Papieski Jana Pawła II w Krakowie
}

\title{
SZACUNEK WOBEC UCHODŹCY Z BLISKIEGO WSCHODU W MEDIACH SPOEECZNOŚCIOWYCH
}

\begin{abstract}
Respect for a refugee from the Middle East in social media. For humanitarian organizations, Facebook is one of the most important social channels of communication with recipients and donors, which is why this communicator was the focus of attention, excluding Instagram, Twitter and other media used to promote the organization. The article deals with the issue of presenting refugees on Facebook by non-governmental organizations. The way in which the image of a refugee is created has an impact on shaping public opinion in social media. The leading question in this paper is: do the organizations accurately represent the image of an asylum seeker? The study discusses good practices for presenting the image of a refugee and the dangers of presenting this image incorrectly. Issues related to the responsible role of non-governmental organizations in creating the image of a refugee from the Middle East were discussed. The article uses the literature on the subject, content analysis, and quantitative analysis of NGOs' Facebook posts.
\end{abstract}

Szacunek wobec uchodźcy z Bliskiego Wschodu w mediach społecznościowych. Dla organizacji humanitarnych Facebook stanowi jeden z najważniejszych społecznościowych kanałów komunikacji z odbiorcami i darczyńcami, dlatego to właśnie na tym komunikatorze została skupiona uwaga, z pominięciem Instagrama, Twittera oraz innych mediów wykorzystywanych do promocji organizacji. W artykule poruszono problematykę przedstawiania uchodźcy na Facebooku organizacji pozarządowych. Sposób, w jaki kreuje się wizerunek uchodźcy, ma wpływ na kształtowanie opinii publicznej w mediach społecznościowych. Pytanie wiodące w niniejszej pracy brzmi: czy organizacje rzetelnie przedstawiają wizerunek azylatna? W opracowaniu zostały omówione dobre praktyki służące prezentacji wizerunku uchodźcy oraz zagrożenia wynikające z niezgodnego 
$\mathrm{z}$ prawdą przedstawiania tego wizerunku. Poruszono zagadnienia związane $\mathrm{z}$ odpowiedzialną rolą organizacji pozarządowych w kreowaniu wizerunku uchodźcy z Bliskiego Wschodu. W artykule wykorzystano literaturę przedmiotu, analizę zawartości, analizę postów $\mathrm{NGO}^{1}$ metodą ilościową.

Keywords social media, respect, dignity, refugee, migration, Middle East, Syria

social media, szacunek, godność, uchodźca, migracja, Bliski Wschód, Syria

Rozwój Internetu, a co się z tym wiąże portali społecznościowych, przyczynił się do generowania i przetwarzania różnych informacji. Media społecznościowe, oprócz interakcji nadawcy z odbiorcą, służą reklamie firm bądź produktów. Nadawcą mediów społecznościowych może być każdy, kto chce wyrazić swoje zdanie, dzięki publikacji wpisu czy odniesieniu się do postów innego odbiorcy w komentarzu ${ }^{2}$. Dziś media społecznościowe pełnią zatem nie tylko funkcję informującą, rozrywkową czy nakłaniającą do zakupu, ale także kształtującą opinię publiczną na dany temat. W mediach społecznościowych poruszane są również zagadnienia kontrowersyjne i trudne społecznie. Jednym z problemów, z jakimi borykają się obecnie kanały społecznościowe, to sposób ukazania migracji w społecznościowych przekazach medialnych ${ }^{3}$. Trwający od 2010 roku kryzys migracyjny bez wątpienia wpłynął na wizerunek uchodźcy. Przyczyn kryzysu można doszukiwać się już w protestach związanych z niezadowoleniem obywateli z bezrobocia, rosnących cen, korupcji oraz z ograniczenia swobód obywatelskich w krajach Bliskiego Wschodu. Protesty zostały nazwane później Arabską Wiosną. Liczba uchodźców zwiększyła się gwałtownie po wybuchu wojny w Syrii w 2011 roku. Obecnie większość ludzi uciekających przed wojną znalazło schronienie w obozach w Turcji, Libanie, Jordanii oraz Irackim Kurdystanie. W sumie w obozach żyje około 4,8 miliona Syryjczyków ${ }^{4}$. Oprócz jednostek Organizacji Narodów Zjednoczonych na miejscu pracują organizacje humanitarne, w tym także polskie jednostki pomocowe, $\mathrm{z}$ których najbardziej zaangażowanymi są: Caritas Polska, Polska Akcja Humanitarna, Polska Misja Medyczna oraz Polskie Centrum Pomocy Międzynarodowej. W codziennych przekazach medialnych to organizacje non-profit stoją na straży godności drugiego człowieka ${ }^{5}$.

Problem z rzeczywistym postrzeganiem uchodźcy ujawnił się w mediach tradycyjnych, a $\mathrm{z}$ biegiem czasu i w wyniku rozwoju technologii zaistniał też w social mediach. Problem $z$ właściwym kształtowaniem opinii w stosunku do uchodźców ma związek z dużym kryzysem uchodźczym w Europie, ale również z niewielką wiedzą na temat odrębnej kultury, jaką jest kultura arabska ${ }^{6}$. Należy jednak pamiętać, że uchodźcą jest również ta osoba, która po wojnie żyje w obozie na Bliskim Wschodzie. Mimo to jest kojarzona z imigrantem przebywającym w Europie czy islamskim ekstremistą. Dodatkowo

1 NGO - skrótowiec od ang. non governmental organization (organizacja pozarządowa).

2 J.W. Wiktor, Komunikacja marketingowa, Warszawa 2013.

3 Narzędzia i techniki komunikacji marketingowej XXI wieku, red. K. Śliwińska, M. Pacut, Warszawa 2011.

4 Por. http://uchodzcy.info/infos/historia (1.03.2020).

5 Por. http://reporting.unhcr.org/node/36 (1.03.2020).

6 L. Leszkowicz-Baczyński, Ewolucja przekonań Polaków wobec „obcych” jako efekt kryzysu migracyjnego w Europie, „Colloquium Wydziału Nauk Humanistycznych i Społecznych AMW” 2018 nr 2, s. 31-48. 
ugrupowania rządowe odegrały ogromną rolę w potęgowaniu niechęci wobec uchodźców w „polityce dystansującej od próby wspólnego rozwiązania kryzysu uchodźczego poprzez solidarne rozlokowanie uchodźców”"

Celem niniejszego artykułu jest analiza, czy i w jakim stopniu szacunek wobec uchodźców jest wyrażany w postach na Facebooku, na podstawie stron wybranych organizacji humanitarnych. Opisywane zjawiska dotyczą uchodźców, którzy pozostali na Bliskim Wschodzie i nie podjęli próby przeniesienia się na inny kontynent. W pracy zostały wykorzystane następujące metody badawcze: literatura przedmiotowa i źródłowa, obserwacja i analiza zawartości 45 postów czterech polskich organizacji pozarządowych: Polskiej Misji Medycznej, Polskiej Akcji Humanitarnej, Caritas Polska, Polskiego Centrum Pomocy Międzynarodowej. Badania prowadzono w okresie od stycznia do maja 2020 roku. Analiza postów wykazała szczątkową zawartość komentarzy, dlatego zostały one uzupełnione metodą ilościową w formie ankiety przeprowadzonej na próbie 85 respondentów z Polski.

\section{ROLA NGO w UKAZYWANIU WAŻNYCH SPOŁECZNIE PROBLEMÓW}

Działanie organizacji pozarządowych we współczesnym świecie jest nieodzownym elementem funkcjonowania państwa i społeczeństwa. Organizacje wypełniają luki w zaspokajaniu potrzeb społecznych. Nie bez powodu wszystkie organizacje pozarządowe noszą wspólne miano sektora 3, zaraz obok instytucji państwowych (sektor 1) i firm komercyjnych (sektor 2). Zgodnie z definicją, organizacja non-profit łączy zorganizowaną grupę osób wokół wspólnego celu i ukierunkowuje ją na osiąganie zmian w określonej społeczności czy zjawisku ${ }^{8}$. Każda wiarygodna organizacja non-profit działa zgodnie z zasadami współżycia społecznego i poszanowania godności drugiego człowieka, co również zostało zapisane w Konstytucji RP 9 .

W ukazywaniu ważnych społecznie problemów znacząca jest rola organizacji pozarządowych. NGO zwracają uwagę na kwestie, które dla rządzących są często niewygodne, a z drugiej strony - są przejawem społecznej aktywności wokół danego tematu ${ }^{10}$. W Polsce z problemem postrzegania uchodźców mierzą się cztery najważniejsze organizacje, których działalność na Facebooku została poddana poniższej analizie.

7 L. Leszkowicz-Baczyński, Ewolucja przekonań Polaków wobec „obcych”, dz. cyt.

8 D. Cianciara, M. Piotrowicz, Rola organizacji pozarządowych (NGOs) w życiu społecznym oraz systemie zdrowotnym. Zakład Promocji Zdrowia i Szkolenia Podyplomowego, „Przegląd Epidemiologiczny”67 (2013) nr 1, s. 151-155.

9 Konstytucja Rzeczypospolitej Polskiej z dnia 2 kwietnia 1997 r., art. 30, Dz. U. 1997 Nr 78, poz. 483.

10 D. Cianciara, M. Piotrowicz, Rola organizacji pozarządowych (NGOs) w życiu społecznym..., dz. cyt., s. $151-155$. 


\section{Analiza postów Polskiej Akcji Humanitarnej}

Polska Akcja Humanitarna (PAH) jest jedną z największych organizacji humanitarnych w Polsce, prowadzących działania na Bliskim Wschodzie od 2003 roku (Irak i Kurdystan). Od 2013 roku organizacja pomaga w Syrii, a od 2 lat również w Jemenie. Główną misją PAH w krajach arabskich jest dostarczanie wody, paczek z żywnością oraz pomoc medyczna. Podstawowym celem organizacji jest zbieranie pieniędzy na pomoc w najuboższych regionach świata ${ }^{11}$.

W swoich działaniach w mediach społecznościowych organizacja ukazuje kryzysy humanitarne w sposób przemyślany. Akcja jest zazwyczaj prowadzona pod hasłem przewodnim, wiodącym przez całą zbiórkę, a wszystkie elementy graficzne są spójne. „Wojna. Mój dom”, „Pomoc nie może pominąć nikogo” - to przykłady haseł przewodnich akcji pomocowych ${ }^{12}$. Działania PAH są zaplanowane i dotyczą różnych obszarów promocji (informacji), np. newsletter, media tradycyjne czy media społecznościowe. W niniejszym artykule skupiono uwagę na tych ostatnich - analizie poddano posty na Facebooku Polskiej Akcji Humanitarnej dotyczące Bliskiego Wschodu z okresu od stycznia do maja 2020 roku. Analogiczne kryterium przyjęto dla pozostałych trzech organizacji.

$\mathrm{PAH}$ prowadzi bardzo spójną identyfikację wizualną, dlatego wszystkie elementy graficzne wykorzystywane w postach są utrzymane w odcieniach koloru niebieskiego, z różowymi akcentami. Na większość zdjęć nałożony jest filtr w ciepłych barwach. Kolor różowy przyciąga wzrok, nawet jeśli zdjęcie nie jest wystarczająco wyraziste.

Formaty wykorzystywane przez PAH są rozmaite, ale większość informacji o działaniach na Bliskim Wschodzie jest ograniczona do formatu zdjęciowego. Inne rodzaje postów wykorzystywane przez fundację to: publikacje z mediów tradycyjnych dodające organizacji wiarygodności, publiczne zbiórki pieniędzy, przekazy wideo i transmisje live prowadzone przez koordynatorów projektów humanitarnych.

Treści towarzyszące grafice lub zdjęciu mają z jednej strony charakter informacyjny, bowiem PAH powołuje się na statystyki (np. dzieci stanowią 46\% wszystkich, którzy musieli uciekać ze swoich domów z powodu wojny w Iraku). Z drugiej strony, opisy do zdjęć są nacechowane emocjonalnie, np. „Nie bądźmy obojętni, pomóżmy!”. Opisy zawierają też swego rodzaju raport z działań misyjnych PAH, np. „Nasze działania to budowa 4 nowych namiotów...”.

Uchodźcy są bohaterami zdjęć, przedstawiani jako „normalne” rodziny żyjące w obozach. Organizacja stara się nie wykorzystywać fotografii pojedynczego, płaczącego dziecka, jednak posty nawołujące do publicznej zbiórki pieniędzy są dużo bardziej nacechowane emocjonalnie niż inne posty. Ukazują odmienne, bardziej dramatyczne tło lub trudną sytuację uchodźców.

11 Por. http://pah.org.pl (15.03.2020).

12 Por. https://www.facebook.com/PolskaAkcjaHumanitarna/posts/10157258976640308 (15.03.2020). 
Rys. 1. Przykłady postów PAH na Facebooku (zrzuty ekranu)

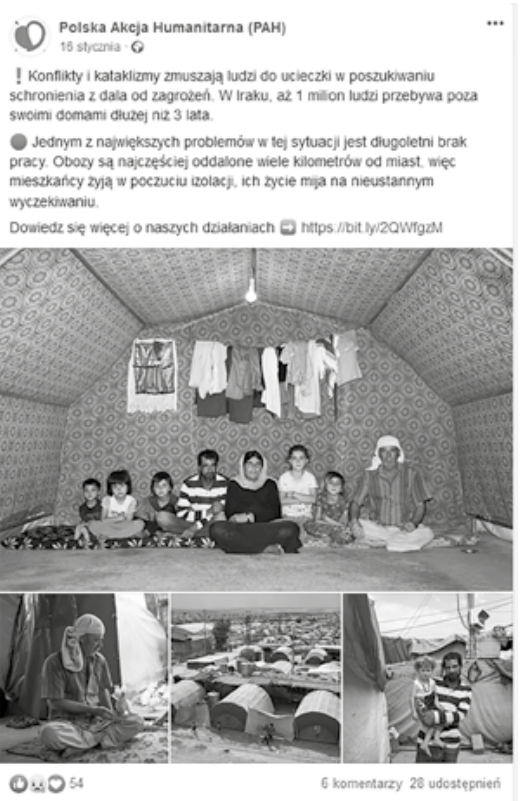
(O) Polska Akcja Humanitarna (PAH) zorganizowal(a) wspólne $\quad$... oglądanie. 22 kwietnia - $\odot$
X W Jemenie jedynie 51\% ośrodków zdrowia jest w pelni funkcionalnych. Jak kraj, w kłórym panuje wojna może poradzić sobie w czasie pandemi koronawirusa?
Aleksandra Wiśniowska, Kierowniczka Misji PAH w Jemenie rozmawia z Jarosław Kużniar LIVE o naszych dzialaniach $\mathbf{D}$
Rozmowa odbywa się w ramach cyklu "Pomoc humanitarna w czasach COVID".
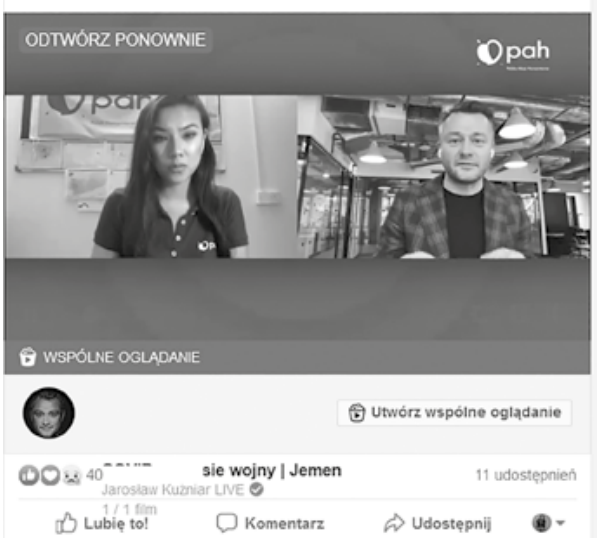

Źródło: www.facebook.pl/PolskaAkcjaHumanitarna (20.04.2020).

Rys. 2. Przykładowe posty PAH na Facebooku (zrzuty ekranu)

Polska Akeja Humanitarna (PAH)

22 lutego 6

Nie bądżmy obojętni pomozmy! Dołącz do zbiórki $]$ https /ibit ly/2SNipYVx $X$ Tyko w ciagu ostatnich kilku ont. porzucić swoje domy musiaio prawie 150 tys. ludzi, w zdecydowanej większości kobiet i dzieci.

Uciekający szukają ratunku w obozach dla uchodżców, ale większośc z nich jest przepeiniona i nie moze przyją́ nikogo. Ludzie spia po prostu na ulcy. pod drzewami. a czasami nawet na polach. wśród śniegu. bez dostepu do wody. jedzenia i toalet.

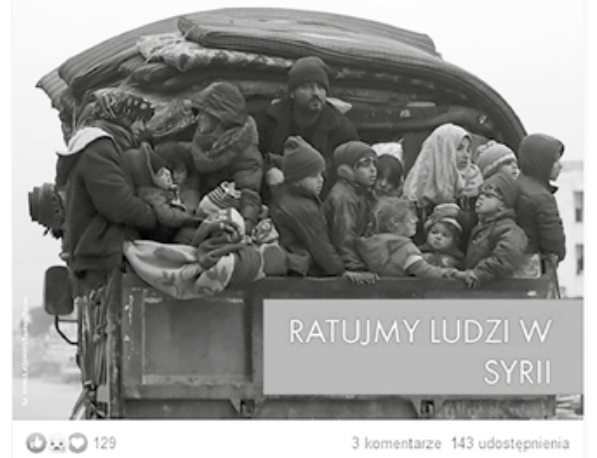

Polska Akcja Humanitarna (PAH)

30 grudria $2019 \cdot 6$

Dzjeci stanowia $46 \%$ wszystoch osobo, htóre musiany uciekat ze swoich dombiw 2 powodu woiny w iraku

Ne bądżny obojętni, pomózny ! To juz ostatnie chwile, zeby dołączyč do

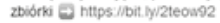

Dręekujemy za Wasce dotychczasome wsparcie!

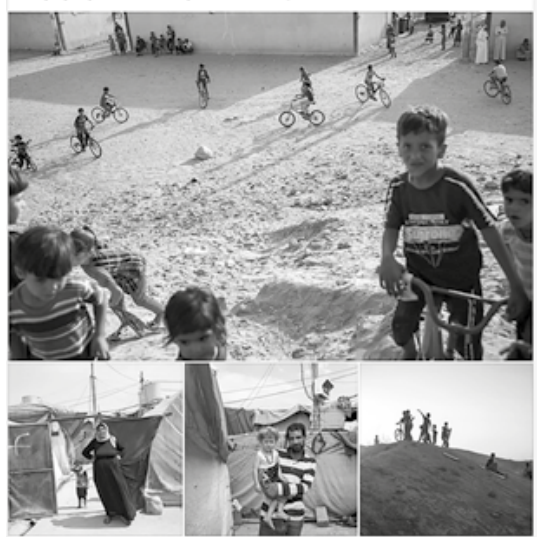

Źródło: www.facebook.pl/PolskaAkcjaHumanitarna (20.04.2020). 


\section{Analiza postów Polskiej Misji Medycznej}

Polska Misja Medyczna (PMM) aktualnie obejmuje pomocą takie kraje, jak: Jordania, Syria oraz Iracki Kurdystan, ale na Bliskim Wschodzie pomaga od 2003 roku. Stowarzyszenie zajmuje się głównie zapewnieniem opieki medycznej w obozach dla uchodźców, a razem $z$ organizacją partnerską prowadzi produkcję protez dla dzieci, które straciły kończyny wskutek wojny w Syriii ${ }^{13}$. Facebook jest dla PMM głównym kanałem komunikacji w mediach społecznościowych. Identyfikacja wizualna nie jest tak bardzo widoczna, ale przewodnie kolory: niebieski i czerwony dają się zauważyć.

Polska Misja Medyczna wykorzystuje różne formaty zdjęć, filmów, publikacji z mediów tradycyjnych, infografik. Te ostatnie są świetnym źródłem wiedzy na temat krajów globalnego Południa (np. „Czy wiesz, że w Jordanii 78\% uchodźców żyje poniżej granicy ubóstwa?”). Treści w postach konstruowane są także z wykorzystaniem wypowiedzi koordynatorów i lekarzy pracujących na Bliskim Wschodzie i mogących udzielić rzetelnych informacji z miejsca działań.

Rys. 3. Przykładowe posty PMM na Facebooku (zrzuty ekranu)
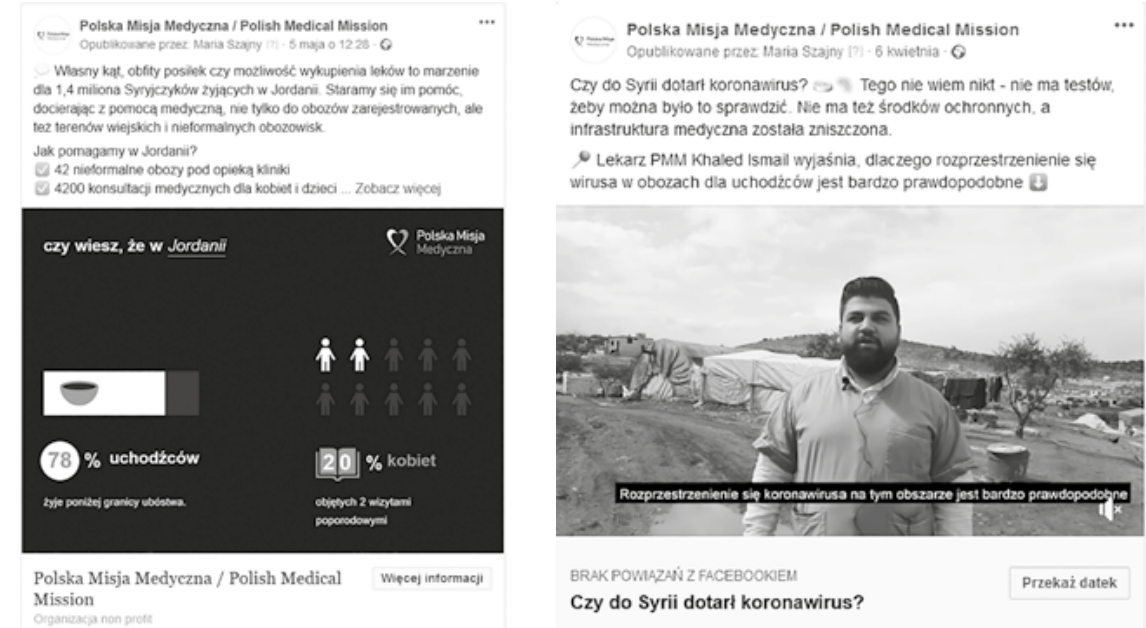

Źródło: www.facebook.pl/PolskaMisjaMedyczna (20.04.2020).

Organizacja posługuje się storytellingiem, aby opisać niektóre zdjęcia, zwłaszcza gdy na fotografii widać jednego bohatera, np. w taki sposób została opisana historia Fatimy dziewczynki, która straciła kończynę. Poza storytelllingiem organizacja powołuje się na statystyki, przygotowuje raporty o działaniach PMM na Bliskim Wschodzie, korzysta $\mathrm{z}$ wiedzy lekarzy - ekspertów w poszczególnych dziedzinach. W przypadku zbiórek publicznych PMM, podobnie jak PAH, wykorzystuje zdjęcia nacechowane emocjonalnie,

13 Por. http://pmm.org.pl (15.04.2020). 
ukazujące krzywdę dzieci i rodzin mieszkających w obozach dla uchodźców. Dla niektórych odbiorców zdjęcia płaczących dzieci ubrudzonych w błocie mogą być zbyt mocne w przekazie.

Rys. 4. Przykłady postów PMM na Facebooku (zrzuty ekranu)
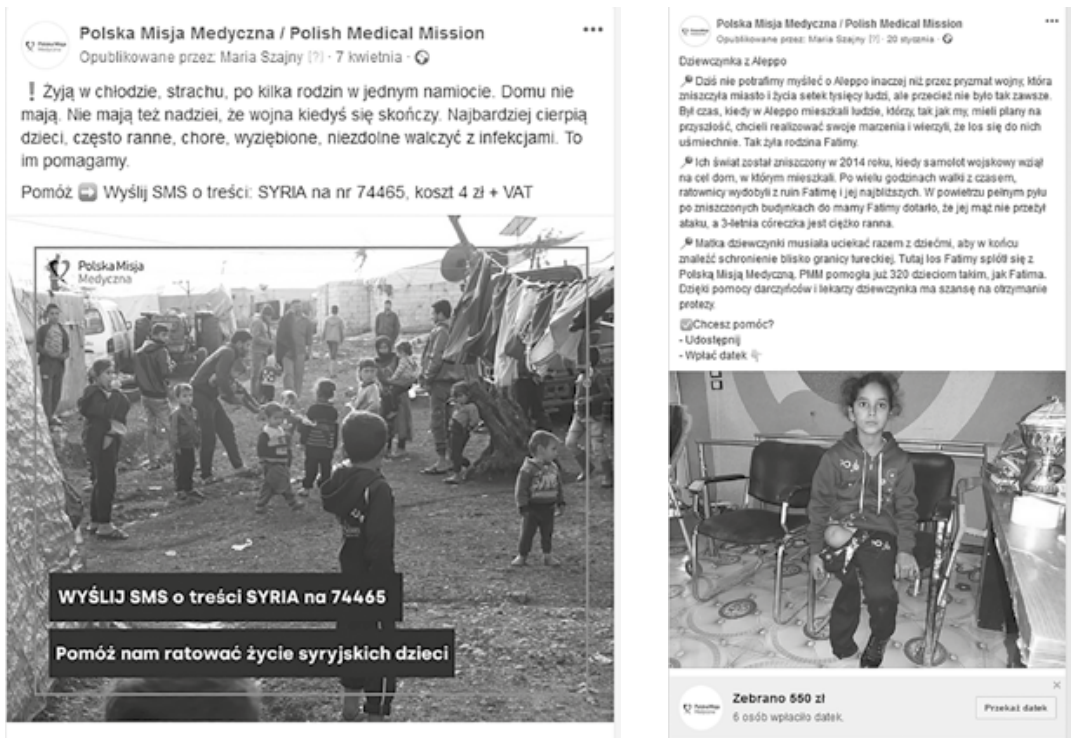

Źródło: www.facebook.pl/PolskaMisjaMedyczna (20.04.2020).

\section{Analiza postów Polskiego Centrum Pomocy MięDZYNARODOWEJ}

Syria, Irak, Liban oraz Palestyna (region oraz państwo nieuznawane przez wszystkie państwa) to kraje bliskowschodnie, w których pomaga Polskie Centrum Pomocy Międzynarodowej (PCPM). Od 2018 roku organizacja zintensyfikowała swoje działania na pomoc syryjskim uchodźcom. Do komunikacji w dużej mierze wykorzystuje media tradycyjne, ale głównymi kanałami społecznościowymi dla PCPM są Facebook i Twitter ${ }^{14}$. Organizacja nie wykorzystuje komunikacji wizualnej w postach dotyczących mieszkańców Bliskiego Wschodu, ale zdarza się, że oznacza zdjęcia logo PCPM. Główną zawartość strony organizacji na Facebooku stanowią publikacje z mediów tradycyjnych. Na 12 analizowanych postów aż 6 odnosiło się do prasy, radia lub telewizji. Oprócz tego typu publikacji na stronie PCPM można znaleźć także zdjęcia dzieci i rodzin w obozach.

14 Por. http://pcpm.org.pl (15.04.2020). 
Rys. 5. Przykłady postów PCPM na Facebooku (zrzuty ekranu)
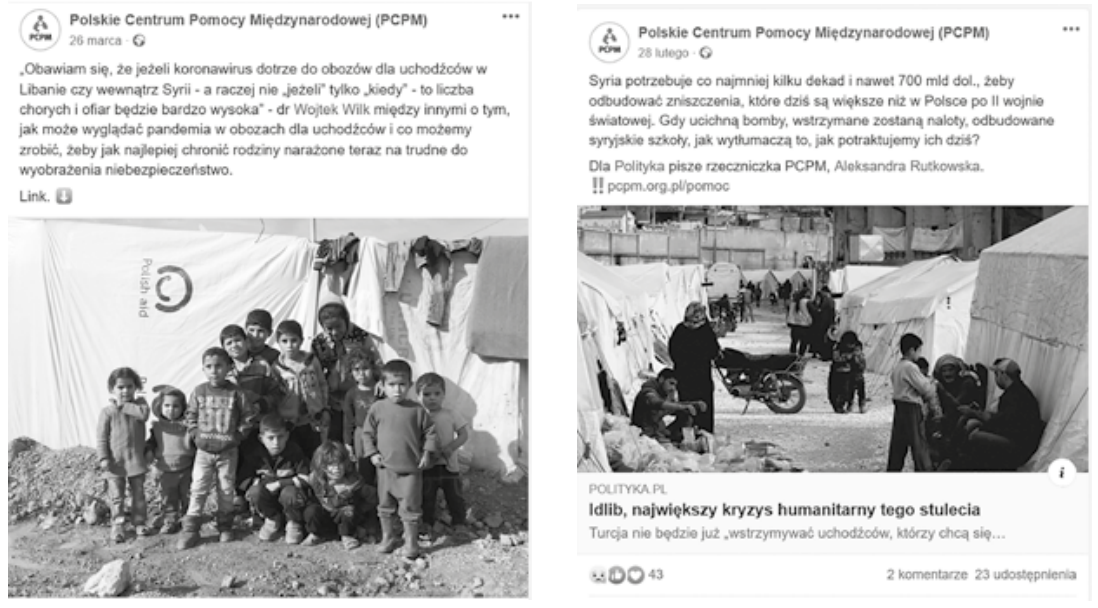

Źródło: www.facebook.pl/PCPM.NGO (20.04.2020).

Opisy zdjęć PCPM zawierają apele o pomoc, relacje z działań pomocowych, odniesienia w cytatach do stanowiska eksperta - założyciela PCPM dr. Wojciecha Wilka, a także fragmenty artykułów publikowanych na stronie internetowej organizacji.

Organizacja wykorzystała jedno zdjęcie w trzech różnych postach na Facebooku: jedno dotyczyło zbiórki publicznej, a dwa kolejne - publikacji w prasie. Zdjęcie mogło być elementem łączącym całą akcję pomocy syryjskim uchodźcom, ale bez hasła i kreacji wygląda jakby było powtórzeniem treści. PCPM bardzo często wykorzystuje zdjęcia z obozów dla uchodźców, obrazujące drastyczne warunki życia.

Rys. 6. Przykłady postów PCPM na Facebooku (zrzuty ekranu)
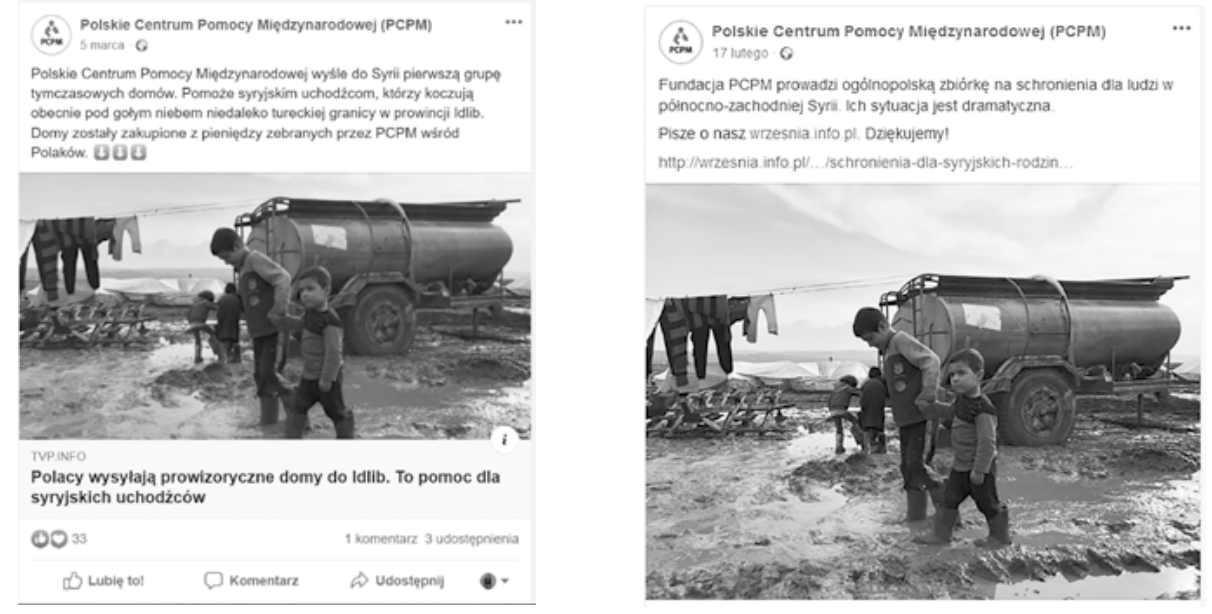

Źródło: www.facebook.pl/PCPM.NGO (20.04.2020). 


\section{Analiza postów Caritas Polska}

Caritas Polska prowadzi na Bliskim Wschodzie bardzo duży projekt humanitarny i medialny pod hasłem „Rodzina Rodzinie”, w ramach którego można wesprzeć finansowo rodzinę syryjską. Programem objęto 9 tysięcy rodzin, a wartość pomocy przekroczyła 55 milionów złotych ${ }^{15}$. Caritas Polska jest obecnie zaangażowana także w pomoc w Jemenie razem z Polską Akcją Humanitarną. Katolicka organizacja charytatywna prowadzi zróżnicowaną komunikację na Facebooku, korzystając między innymi z tzw. albumów ze zdjęciami, infografik, filmów i publikacji w mediach. Nie wyróżnia swoich projektów żadną identyfikacją wizualną, tak jak dzieje się to w przypadku Polskiej Akcji Humanitarnej.

Opisy w postach Caritas Polska są zróżnicowane. Te dotyczące akcji \# rodzinarodzinie zawierają krótką, storytellingową historię rodziny. Pozostałe wyróżniają się apelem o pomoc, bardzo emocjonalną oceną sytuacji.

Rys. 7. Przykłady postów Caritas Polska na Facebooku (zrzuty ekranu)
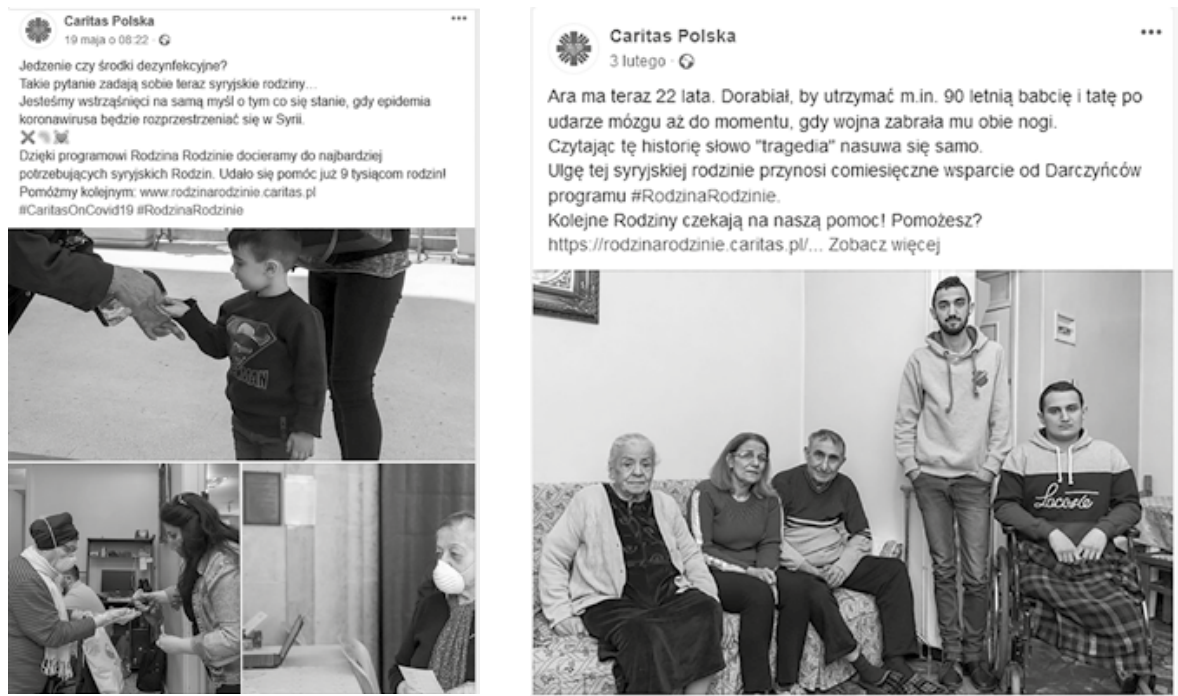

Źródło: www.facebook.pl/CaritasPL (20.04.2020).

Jeśli chodzi o odpowiednie wykorzystanie zdjęć, organizacja przechodzi ze skrajności w skrajność, publikując z jednej strony grafiki informacyjne, a drugiej strony fotografie płaczących dzieci. Zazwyczaj jednak rodziny syryjskie przedstawiane są z należytym szacunkiem. Podobnie w przypadku używania znaków graficznych - emotikon; czasem jest ich bardzo dużo, a niekiedy nie ma ich wcale.

15 Por. https://caritas.pl (15.03.2020). 


\section{OBSERWACJE}

Podsumowując analizę postów dotyczących mieszkańców Bliskiego Wschodu, można stwierdzić, że każda organizacja prezentuje wyróżniający ją punkt: Polska Akcja Humanitarna bardzo dba o identyfikację wizualną, PCPM stara się zachować w mediach społecznościowych stanowisko eksperckie, prezentując treści z wykorzystaniem publikacji w mediach tradycyjnych. Polska Misja Medyczna tworzy urozmaicony content, wykorzystujący zdjęcia i filmy nie tylko uchodźców, lecz także lekarzy i koordynatorów, z kolei Caritas Polska, oprócz ukazania sylwetki osoby, tworzy grafiki opierające się na danych statystycznych.

Przechodząc do kwestii etycznych, wydaje się, że organizacje posiadają wiedzę na temat etyki komunikacji i mówienia o uchodźcy, lecz nie zawsze odpowiednio ją wykorzystują. Porównując wszystkie cztery organizacje, można zaobserwować, że PAH zdaje się zwracać największą uwagę na wierne przedstawianie wizerunku azylantów.

Obrazy w mediach to nie tylko zdjęcia i filmy, lecz także treści, które kreują pewien nacechowany obraz. Dlatego ważne jest zwrócenie uwagi na to, jakie przymiotniki stosuję się do opisu sytuacji lub bohatera. Słowa budujące opis odgrywają ważną rolę. Na przykład zdanie: „Uchodźcy uciekli i koczują na granicy syryjsko-tureckiej” w porównaniu ze zdaniem: „Uchodźcy zostali zmuszeni do opuszczenia swoich domów i obecnie przebywają w nieformalnych obozach przy granicy" nie obrazuje rzeczywistej sytuacji uchodźców i może wprowadzić odbiorcę w błąd w ich postrzeganiu.

\section{ANAliza POSTRZEgania SPOSOBU KOMUNIKACJI ORgANIZACJI PRZEZ SPOŁECZNOŚĆ}

Polskimi organizacjami, które prowadzą działania na rzecz pomocy uchodźcom z Bliskiego Wschodu są: Polska Akcja Humanitarna, Polska Misja Medyczna, Polskie Centrum Pomocy Międzynarodowej oraz Caritas Polska. Ich sposób przekazu informacji z odbiorcami za pomocą Facebooka został poddany analizie na podstawie ankiety.

Ankieta dotycząca odbioru komunikatów o uchodźcach z Bliskiego Wschodu na stronach na Facebooku czterech polskich organizacji humanitarnych została przeprowadzona wśród 85 respondentów. 56\% ankietowanych nie posiada żadnego doświadczenia związanego z PR oraz mediami społecznościowymi, a $93 \%$ to osoby w wieku od 18 do 36 lat, a więc należące do tzw. pokolenia Y i Z, które korzystają na co dzień z telefonu $\mathrm{z}$ aplikacjami social mediów jako podstawowego środka komunikacji. Wartością dodaną jest fakt, że 81,2\% respondentów nie obserwuje stron żadnej z wymienionych organizacji. Na tej podstawie można wnioskować, że badani patrzą na posty „świeżym okiem” i nie kierują nimi żadne więzi z marką. Z jednej strony ankieta potwierdza prawidła zawarte $\mathrm{w}$ dobrych praktykach wymienionych poniżej, a z drugiej zaś dostarcza zaskakujących pod wieloma względami odpowiedzi. 
W pierwszym pytaniu ankietowani mieli wybrać, biorąc pod uwagę jedynie kreację posta, którą zbiórkę najchętniej by wsparli. Każda z czterech kreacji dotyczyła jednej organizacji, a wyglądały one następująco:

Rys. 8. Zbiórki na Facebooku prowadzone przez opisywane organizacje pozarządowe

Caritas Polska

25 lutego $\cdot 6$

! Oni czekają na Twoja pomoc !

Czytales? Slyszaleś? Oglądales w TV? Czekamy na Twơj ruch.

W Jemenie trwa największy kryzys humanitarny: głód, choroby, brak dostępu do wody i leków - to ich codziennosc. in

Przekaz darowiznę - kilka kliknięc moze uratować ludzkie zycie.

https I/Www. facebook.com/donate/2547347165537636/

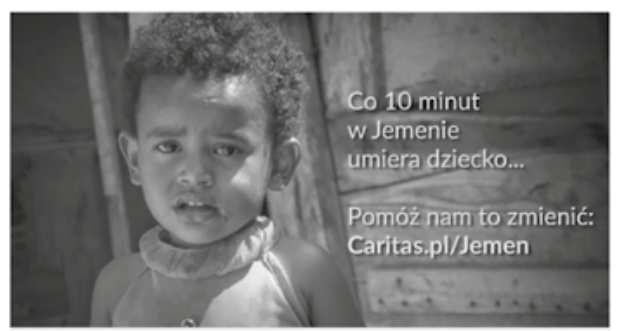

이리 Ratujmy tych, o których świat zapomniał!

Zbiorrka pieniędzy, ktơrej organizatorem jest Caritas Polska

| W Jemenie co 10 minut smiercia glodowa umiera dziecko | Głod, choroby $m$ in. epidemia cholery i brak dostępu po... Czytaj dalej

Polskie Centrum Pomocy Międzynarodowej (PCPM) 20 lutego - 6

! Nasza zbiórka caly czas trwa. Do osiagnięcia pienwszego celu brakuje $\mathrm{C}$ 1444 PLN. Prosimy o udostępnienia!

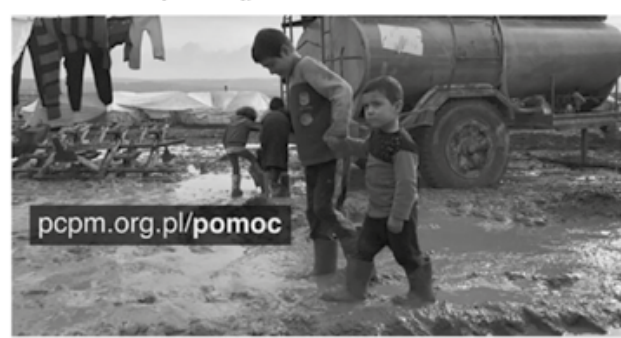

\footnotetext{
8. PILNE II Schronienia dla syryjskich rodzin

PCPM Zbiórka pleniędzy, której organizatorem jest Polskie Centrum Pomocy Międzynarodowej (PCPM)
}

Sytuacja ludzi w północno-zachodniej Syni jest dramatyczna. Tylko w ciaggu ostatnich dwóch miesięcy z domów musi... Czytaj dalej

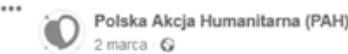

I! Apelujemy o pomoci Zagrozone jest zycie prawie 3 milionow mieszkaricow Syril

Mark Lowcock, zastepca sekretarza generalnego ONZ ds humanitarnych, opisai sytuację w Idlib jako, największą horror humanitarny XXI wieku"

Pomóz $\boxminus$ wplać $\boxminus$ podaj dalej $\boxminus$ zapros znajomych do zbiớrkil

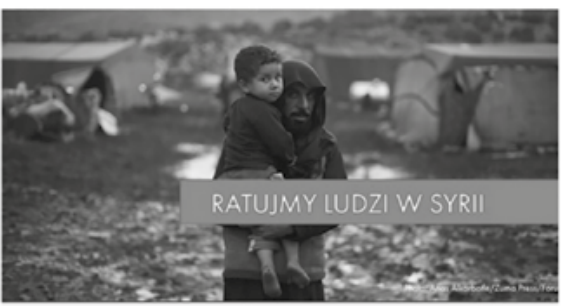

'P RATUJMY LUDZI W SYRII! Potrzebuja pomocy bardziej niź kiedykolwiek

Zbiórka pieniẹdzy, której organizatorom jost Polska Akcja Humanitarna (PNH)

Ludzie w Syrii pilnie potrzebuja naszej pomocyl Wojna znowu zmusila ich do opuszczenia swoich domów. Muszą uciek.. Czytaj dalej

Zebrano $55323 \mathrm{zl}$ z $50000 \mathrm{zl}$

Zakoniczona

Polska Misja Medyczna / Polish Medical Mission

Opubikowane przez Maria Szajny in] - 28 lutego - 0

! Prosimy o pomoc razem z lekarzami z Humanitarian Message. Milion Syryjczyków ucieklo $z$ prowincij Idib

- Ofiarami staja się niewinni ludzie, wsrơd nich kobiety i dzieci. To oni potrzebuja speciainei, natychmiastowej opieki. - mowi Mansour Alatrash. lekarz wspolpracujący z PMM, który jest na miejscu.

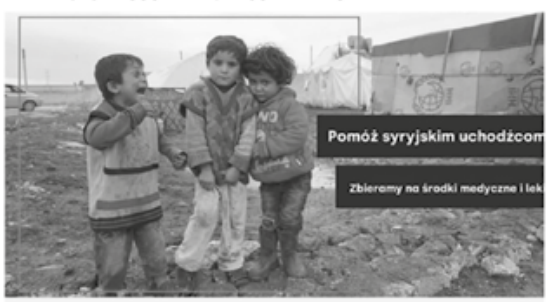

PILNIE Pomoc medyczna dla uchodźców z Idlib

$\mathrm{Q}=$ Zbiórka pieniędzy, kłórej organizatorem jest Polska Misja Medyczna / Polish Medical Mission

Syryjscy lekarze z Humanitarian Message proszą Polaków o pomocl Polska Misja Medyczna zbiera fundusze na srodki ... Czytaj dalej

Źródło: www.facebook.com/PolskaMisjaMedyczna/posts/3175631509122855,

www.facebook.com/PCPM.NGO/posts/2783074051771558,

www.facebook.com/PolskaAkcjaHumanitarna/posts/10157101367090308 www.facebook.com/CaritasPL/ posts/2994900563907552 (20.04.2020). 
Zgodnie z odpowiedziami ankietowanych, zbiórką, która uzyskała największą aprobatę, była zbiórka zorganizowana przez Caritas Polska. Ta kreacja należy do najmniej drastycznych, ale oddaje sedno problemu, jakim jest klęska głodu w Jemenie. Zbiórka przyniosła najmniejsze przychody, ale warto zauważyć, że na sukces akcji pomocowej składają się także liczne inne czynniki, dlatego nie można ocenić jej jednoznacznie, biorąc pod uwagę jedynie post w mediach społecznościowych.

Rys. 9. Ankieta dotycząca postrzegania uchodźców z Bliskiego Wschodu

Która, ze zbiórek budzi w Tobie największą chęć do wsparcia finansowego akcji? Nie bierz pod uwagę marki ani zebranej kwoty, tylko kreację posta.

85 odpowiedzi

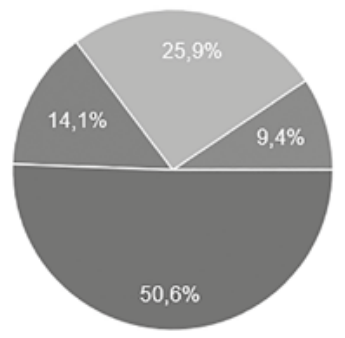

Caritas Polska

Polska Misja Medyczna

Polska Akcja Humanitarna

Polskie Centrum Pomocy

Międzynarodowej

Źródło: materiały własne.

Kolejnym zagadnieniem poddanym analizie w ankiecie była adekwatność opisu do sytuacji panującej w jednym z krajów bliskowschodnich. Respondenci mieli do wyboru następujące opisy:

\section{Opis 1.}

14 Dziś mija 9 lat od wybuchu knwawego konfliktu w Syrii.

Milion osób, w tym pół miliona dzieci, musiało w ostatnich trzech miesiącach uciekać przed bombami spadającymi na syryjską prowincję Idlib. Niektórzy już po raz siódmy od początku wojny domowej opuszczają swoje tymczasowe schronienia. Apelujemy o pomoc!

"0, Wpłać darowiznę przez stronie www.ı

No, Obejmij wsparciem konkretną rodzinę za pośrednictwem strony

Udostẹpnij ten post, by włączyć w pomoc Twoich znajomych!

Chcesz poznać konkretne rodziny, którym pomagamy?

Wejdź na:

\#RodzinaRodzinie \#Syria \#wojna

Źródło: www.facebook.com/CaritasPL/posts/3032640950133513 (20.04.2020). 


\section{Opis 2.}

! Ciąg dalszy kryzysu północno-zachodniej Syrii. Potwierdzono śmierć 4 osób z wychłodzenia !

Z Z Idlib uciekło w ciągu ostatnich dni 140000 osób. Rodziny, którym się "poszczęściło" mogą zatrzymać się w namiotach u swoich znajomych, którzy wcześniej trafili do obozów.

Ci, którzy nie mieli tyle szczęścia, zdani są na siebie. Nie mają schronienia. Żyją z dziećmi w zimnie i chłodzie.

W Syrii Polska Misja Medyczna finansuje dostawy leków ratujących życie, opatrunków, środków do znieczulenia i odkażania. Trafiają one do lekarzy pracujących w szpitalach prowadzonych przez Humanitarian Message Organization.

Źródło: www.facebook.com/PolskaMisjaMedyczna/posts/3150675944951745 (20.04.2020).

\section{Opis 3.}

Nie bądźmy obojętni pomożmy! Dołącz do zbiórki $\Rightarrow$ https://bit.ly/2SNPYVx X Tylko w ciągu ostatnich kilku dni, porzucić swoje domy musiało prawie 150 tys. ludzi, w zdecydowanej większości kobiet i dzieci.

Uciekający szukają ratunku w obozach dla uchodźców, ale większość z nich jest przepełniona i nie może przyjąć nikogo. Ludzie śpią po prostu na ulicy, pod drzewami, a czasami nawet na polach, wśród śniegu, bez dostępu do wody, jedzenia i toalet.

Źródło: www.facebook.com/PolskaAkcjaHumanitarna/photos/a.106789015307/10157072360415308 (20.04.2020).

\section{Opis 4.}

Sytuacja ludzi w północno-zachodniej Syrii jest dramatyczna. Tylko w ciągu ostatnich trzech miesięcy ze swoich domów musiało uciekać 900 tys. ludzi, głównie kobiety i dzieci. Syryjskie rodziny tłoczą się w na małym terenie pośrodku pól, bez dróg, szpitali, szkół i kanalizacji.

Dlatego prosimy o Waszą pomoc. I bardzo dziękujemy za dotychczasowe wsparcie. PCPM.ORG.PL/POMOC

Źródło: www.facebook.com/PCPM.NGO/videos/131858801468198 (20.04.2020).

Na podstawie odpowiedzi ankietowanych można wskazać, że posty Caritas Polska są najlepszym źródłem opisującym sytuację w Syrii. Tytułem komentarza - w moim odczuciu - najbardziej zasadne byłoby postawienie znaku równości między opisami Caritas Polska, PMM i PCPM. 
Rys. 10. Ankieta dotycząca opisu posta organizacji pozarządowych

\section{Które copy posta Twoim zdaniem najlepiej opisuje sytuację w Syrii?}

85 odpowiedzi

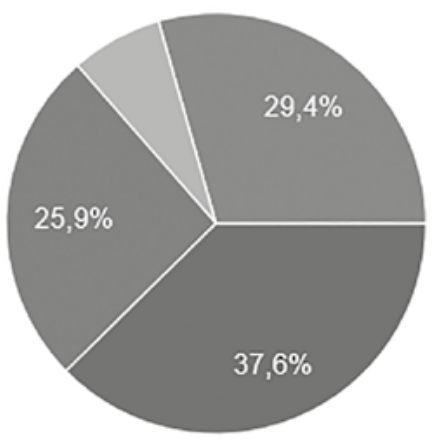

Źródło: materiały własne.

Ostatnie pytanie dotyczyło kreacji budzącej skrajne i negatywne emocje. Ankietowani mieli do wyboru jedno spośród czterech zdjęć.

Rys. 11. Zdjęcia z postów na Facebooku opisywanych organizacji pozarządowych
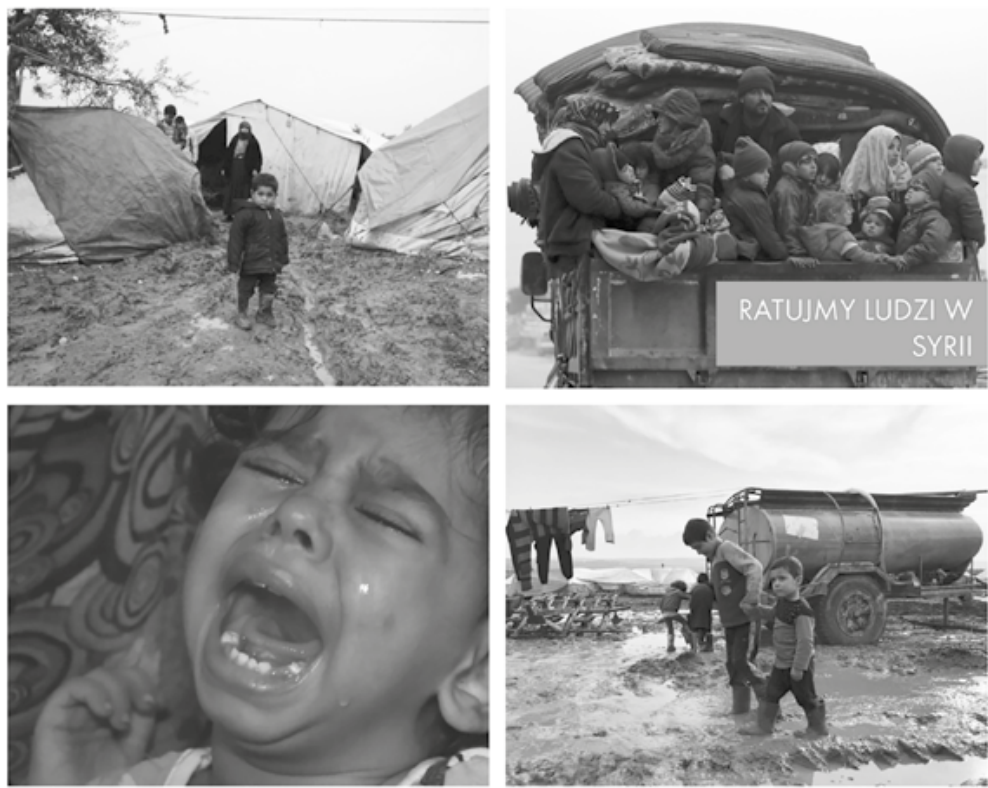

Źródła: www.facebook.com/PolskaMisjaMedyczna/posts/3150675944951745,

www.facebook.com/PCPM.NGO/posts/2783074051771558,

www.facebook.com/PolskaAkcjaHumanitarna/photos/a.106789015307/10157072360415308,

www.facebook.com/CaritasPL/posts/2978767322187543 (20.04.2020). 
Rys. 12. Ankieta dotycząca wyboru posta budzącego negatywne emocje

Które z zdjęć wykorzystanych w postach organizacji budzi w Tobie najwięcej negatywnych emocji i uważasz, że nie powinno zostać użyte?

85 odpowiedzi

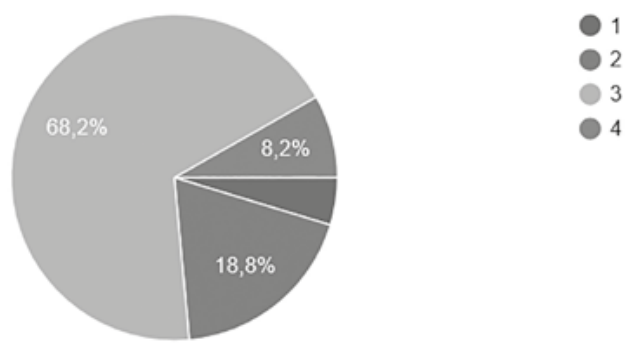

Źródło: materiały własne.

Być może taka niechęć do zdjęcia PAH wynika z negatywnego skojarzenia przez polskiego odbiorcę uchodźców z imigrantami przybyłymi do Europy przed wojną i w jej trakcie, co zostało wspomniane we wstępie niniejszego artykułu. Pomimo że na zdjęciu przedstawiony jest bohater zbiorowy (przypuszczalnie rodzina), budzi on sprzeczne skojarzenia i pozostawia odbiorcy przestrzeń, by resztę historii dopowiedział sobie sam.

\section{DOBRE PRAKTYKI UKAZYWANIA WIZERUNKU UCHODŹCY W MEDIACH SPOEECZNOŚCIOWYCH}

Ogromnym zagrożeniem dla współczesnego wizerunku uchodźcy jest tzw. white savor syndrome. tj. syndrom białego zbawcy - określający człowieka, który dzieli ludzi na białych (silnych) i ciemnoskórych (słabszych), „traktując ich jako rekwizyt dla pokazania zachodniej dobroczynności” ${ }^{16}$. Tematem głośnych dyskusji wielu ekspertów ds. edukacji globalnej, a także dziennikarzy społecznych, był billboard promujący nowy projekt i wywiad przeprowadzony z Dominiką Kulczyk, przedsiębiorcą i prezesem Kulczyk Foundation. Billboard promujący program z udziałem Kulczyk Efekt Domina przedstawiał na pierwszym planie ciemnoskóre dziecko trzymane na rękach przez Dominikę Kulczyk. Billboard został oceniony jako rażąco nieetyczny i potęgujący omówiony wyżej syndrom białego zbawcy. Eksperci zadawali pytania, czy rodzice dziecka wyrazili zgodę na wykorzystanie jego wizerunku w celach komercyjnych, które nie mają nic wspólnego z pomocą. Z kolei po publikacji wywiadu w „Wysokich Obcasach”

$16 \mathrm{https} / /$ krytykapolityczna.pl/swiat/kto-potrzebuje-wiecej-bialych-zbawcow (15.03.2020). 
zarzucano Kulczyk brak znajomości poruszanego przez nią tematu, a samej autorce wywiadu - nierzetelność i brak dociekliwości dziennikarskiej ${ }^{17}$.

Istnieje swego rodzaju kodeks zachowań, którego powinno się przestrzegać w odniesieniu do krajów globalnego Południa. Odchodzi się od przedstawiania uchodźców jako męczenników, a coraz częściej oddaje się im głos, pozwala mówić o swoich problemach ${ }^{18}$.

Na przestrzeni lat zostały opracowane i sformalizowane zasady mówienia o mieszkańcach krajów globalnego Południa (niegdyś nazywane krajami Trzeciego Świata). Osiem najważniejszych zasad, którymi powinny się kierować przede wszystkim organizacje zajmujące się pomocą humanitarną, brzmią następująco ${ }^{19}$ :

1. „Dokonywać wyboru obrazów i wiadomości z poszanowaniem równości, solidarności i sprawiedliwości” - należy zachować godność i prywatność osoby portretowanej ${ }^{20}$.

2. „Prawdziwie przedstawiać wszelkie obrazy i sytuacje - zarówno w bezpośrednim, jak i w szerszym kontekście, dążąc do zwiększenia powszechnego zrozumienia realiów i złożoności procesu rozwoju” - warto zamieścić w wideo tło sytuacji, dzięki któremu można uniknąć nieporozumień lub niewłaściwej interpretacji danego obrazu ${ }^{21}$.

3. „Unikać obrazów i wiadomości mogących szerzyć stereotypy, wywoływać sensację lub dyskryminować ludzi, sytuacje czy miejsca" - warto pokazywać obrazy w szerszym kontekście; zdjęcie Masaja w tradycyjnym stroju nie oznacza, że mieszkańcy Afryki ubierają się tak na co dzieńn ${ }^{2}$.

4. „Wykorzystywać obrazy, wiadomości i badania jednostkowych przypadków z pełnym zrozumieniem, uczestnictwem i za zgodą zainteresowanych (lub ich rodziców czy opiekunów)" ${ }^{23}$.

5. „Zagwarantować, że osoby, których sytuację przedstawiamy, mają możliwość opowiedzenia swojej historii osobiście" 24 .

6. „Ustalić i zanotować, czy opisywane lub portretowane osoby zgadzają się na ujawnienie swoich personaliów i twarzy, i zawsze postępować zgodnie z ich życzeniem" ${ }^{25}$.

7. „Działać zgodnie z najwyższymi standardami w zakresie praw człowieka i ochrony osób słabszych" ${ }^{26}$.

8. „Działać zgodnie z najwyższymi standardami w zakresie ochrony praw dziecka, przestrzegając zapisów Konwencji Praw Dziecka"27.

Ważnym elementem komunikacji na Facebooku jest wcześniejsze zaplanowanie strategii social media, a następnie treści, które zostaną opublikowane. Dzięki temu

17 Por. http://magdalenakrukowska.pl/dominika-kulczyk-znow-pomaga (15.04.2020).

18 D. Gadzinowska, G. Lipska-Badoti, M. Wojtalik, Jak mówić o większości świata. Rzetelna edukacja w Krajach Globalnego Południa, Warszawa 2012.

19 D. Gadzinowska, G. Lipska-Badoti, M. Wojtalik, Jak mówić o większości świata..., dz. cyt.

20 D. Gadzinowska, G. Lipska-Badoti, M. Wojtalik, Jak mówić o większości świata..., dz. cyt.

21 D. Gadzinowska, G. Lipska-Badoti, M. Wojtalik, Jak mówić o większości świata..., dz. cyt.

22 D. Gadzinowska, G. Lipska-Badoti, M. Wojtalik, Jak mówić o większości świata..., dz. cyt.

23 D. Gadzinowska, G. Lipska-Badoti, M. Wojtalik, Jak mówić o większości świata..., dz. cyt.

24 D. Gadzinowska, G. Lipska-Badoti, M. Wojtalik, Jak mówić o większości świata..., dz. cyt.

25 D. Gadzinowska, G. Lipska-Badoti, M. Wojtalik, Jak mówić o większości świata..., dz. cyt.

26 D. Gadzinowska, G. Lipska-Badoti, M. Wojtalik, Jak mówić o większości świata..., dz. cyt.

27 D. Gadzinowska, G. Lipska-Badoti, M. Wojtalik, Jak mówić o większości świata..., dz. cyt. 
wiadomo, co organizacja będzie zamieszczać, a co jest niezgodne z ustaloną strategią. Wśród dobrych praktyk można wymienić między innymi:

1. Oddanie głosu uchodźcom w sposób rzetelny - w przekazie medialnym lub społecznościowym bardzo ważne jest, kto mówi: czy są to bohaterowie, czy dziennikarz. Oddanie głosu bohaterom materiału audiowizualnego, a następnie wykorzystanie wypowiedzi z zachowaniem obiektywizmu zwiększa wiarygodność, przy jednoczesnym zachowaniu zasad etycznych ${ }^{28}$.

2. Pokazanie działań organizacji na miejscu, współpracy z organizacjami lokalnymi - wiele organizacji niosących pomoc w krajach globalnego Południa nie działa samodzielnie, lecz współpracuje z organizacjami powstałymi na miejscu. Pracownicy takich organizacji są niezwykle cennym źródłem informacji o beneficjentach, a przy okazji znają lokalną kulturę, język i obyczaje. Przedstawianie wizerunku osób, które na co dzień są odpowiedzialne za niesienie pomocy humanitarnej, w tym medycznej, jest pozytywnym zjawiskiem i ważnym aspektem przeciwdziałania kompleksowi białego zbawcy $^{29}$.

3. Przedstawianie scen z życia ludzi zgodnie z rzeczywistym stanem - beneficjenci niejednokrotnie wykazują się dużym bohaterstwem i siłą, radząc sobie ze stratą bliskich lub majątku w wyniku starć wojennych. Pokazywanie ich w momentach bezradności, lęku, płaczu jest uznawane za nieetyczne. Zamiast podkreślania ich słabości, lepiej skupić się na eksponowaniu ich hartu ducha, aby utrwalać w social mediach wizerunek osoby nieskrępowanej i potrafiącej myśleć samodzielnie ${ }^{30}$.

Organizacje pozarządowe - z uwagi na świadczoną pomoc - mają niejako pierwszeństwo w budowaniu narracji, kierowaniu komunikacją z odbiorcami, dlatego bardzo ważne jest, aby kreacja była jak najbardziej zbliżona do rzeczywistości i wyrażała szacunek do drugiego człowieka ${ }^{31}$.

\section{Podsumowanie}

Polskie organizacje pozarządowe odgrywają bardzo ważną i odpowiedzialną rolę w kształtowaniu opinii publicznej. Na nich spoczywa odpowiedzialność prawdziwego przedstawiania wizerunku uchodźcy w mediach społecznościowych, który jednak nie zawsze kreowany jest zgodnie z obowiązującymi zasadami. Organizacje mają do dyspozycji narzędzia umożliwiające rzetelne przedstawienie obrazu świata uchodźcy. Każda z opisywanych organizacji ma element wyróżniający, który ułatwia identyfikację. W kształtowaniu obrazu i dbaniu o zachowanie szacunku wobec uchodźcy ważnym czynnikiem jest dostosowanie odpowiedniej, nienacechowanej negatywnie treści przekazu do obrazu. Dzięki rzetelnej wiedzy, przekazywanej za pomocą mediów

\footnotetext{
28 Por. https://www.youtube.com/watch?v=3zx5b3aQyhw\&feature=youtu.be (1.04.2020).

29 Por. https://www.youtube.com/watch? $v=3 z x 5 b 3 a Q y h w \& f e a t u r e=y o u t u . b e ~(1.04 .2020)$.

30 Por. https://www.youtube.com/watch?v=3zx5b3aQyhw\&feature=youtu.be (1.04.2020).

31 Por. http://trendnomad.com/jak-poprawic-wizerunek-uchodzcow-w-mediach (1.04.2020).
} 
społecznościowych, kreowanie wizerunku uchodźcy w informacjach o mieszkańcach obozów na Bliskim Wschodzie ma szansę, żeby przejść pozytywną przemianę. Stosując się do ogólnie przyjętych zasad i dobrych praktyk, można uniknąć niedopowiedzeń i nie wywoływać krzywdzących skojarzeń. Niniejsza praca odnosi się jedynie do części złożonego systemu mediów społecznościowych oraz kreowania prawdziwego wizerunku jednostek społecznych. Żywię nadzieję, że artykuł stanowi wstęp do rozbudowanego projektu badawczego nad wizerunkiem uchodźcy w mediach społecznościowych.

\section{LITERATURA}

Cianciara D., Piotrowicz M., Rola organizacji pozarzadowych (NGOs) w życiu spolecznym oraz systemie zdrowotnym, Zakład Promocji Zdrowia i Szkolenia Podyplomowego Narodowego Instytutu Zdrowia Publicznego - Państwowego Zakładu Higieny w Warszawie, „Przegląd Epoidemiologiczny" 67 (2013) nr 1, s. 151-155.

Gadzinowska D., Lipska-Badoti G., Wojtalik M., Jak mówić o większości świata. Rzetelna edukacja w Krajach Globalnego Poludnia, Warszawa 2012.

Leszkowicz-Baczyński L., Ewolucja przekonań Polaków wobec „obcych” jako efekt kryzysu migracyjnego w Europie, "Colloquium Wydziału Nauk Humanistycznych i Społecznych AMW” $2018 \mathrm{nr} 2$, s. 31-48.

Narzędzia i techniki komunikacji marketingowej XXI wieku, red. K. Śliwińska, M. Pacut, Warszawa 2011.

Wiktor J.W., Komunikacja marketingowa, Warszawa 2013.

\section{ŹródeA INTERNETOWE}

https://krytykapolityczna.pl/swiat/kto-potrzebuje-wiecej-bialych-zbawcow (15.04.2020). http://magdalenakrukowska.pl/dominika-kulczyk-znow-pomaga (15.04.2020). http://trendnomad.com/jak-poprawic-wizerunek-uchodzcow-w-mediach (15.04.2020). https://www.youtube.com/watch?v=3zx5b3aQyhw\&feature=youtu.be (1.04.2020). http://uchodzcy.info/infos/historia (1.03.2020).

http://reporting.unhcr.org/node/36 (1.03.2020). www.pmm.org.pl www.pah.org.pl www.caritas.pl www.pcpm.org.pl 